ISSN: $2576-2141$

\title{
The Perceptions of Private and Suburban Public Schools among Middle Class Urban Parents: Evidence from Albany, New York
}

\author{
Paul T. Knudson ${ }^{1}$ \\ Methodist University
}

\begin{abstract}
Substantial research has examined urban middle class parents and their motivations for enrolling their children in city public schools. Less research, however, has explored how these types of parents view private schools and suburban public schools. Using in-depth interviews with parents and guided by the frameworks of rational choice and social identity theories, this paper explores this topic. Findings suggest that both instrumental and philosophical factors affect parents' perceptions of private schools and suburban public schools. Parents tended to be skeptical of the purported, superior quality of education in both private and suburban public schools. They also felt these schools offered neither advantages surrounding the social/peer climate, nor in college preparation. In addition, parents believed that enrolling their children in either private schools or suburban public schools would undermine their egalitarian and inclusive social and political values.
\end{abstract}

KEYWORDS: Urban Education, Schools, School Choice, Private and Suburban Public Schools.

\section{Introduction}

Few institutions are as central to families and communities as schools. The quality (or perceived quality) of public schools has enormous implications on households' neighborhood and housing choices, property values, economic and racial segregation, and overall community vitality (Chiodo, Hernández-Murillo, \& Owyang, 2010; Johnson \& Nazaryan, 2019; Sikkink \& Emerson, 2008). In many smaller communities the neighborhood public school is the only option families have, whereas in larger metropolitan areas, parents might have a selection of public-neighborhood, public-magnet, private-secular, private-sectarian, and charter schools. For most parents, the school their children attend is primarily a personal matter, and their focus is chiefly on how their own children are progressing academically and socially (Lareau, 2014). Recent scholarship, however, has suggested that "choice" in K-12 education is a matter of degree and rests on the social, cultural, and financial capital of families and groups (Kimelberg, 2014; Posey, 2012; Posey-Maddox, 2016; Posey-Maddox, Kimelberg, \& Cucchiara, 2016; Sattin-Bajaj \& Roda, 2018). Because of these factors education and school choice are also deeply institutional and political (Roda, 2018).

\footnotetext{
${ }^{1}$ Corresponding Author. Paul Knudson, e-mail: pknudson@methodist.edu
} 
This paper explores a relatively unique set of parents and examines their school choices. It focuses on middle class parents living in a central city, who despite having the resources for either private schools or relocating to suburbs with higher-ranking public schools, have decided to remain in the central city and enroll their children in public schools. Reay, Crozier and James (2011) labeled these families 'against the grain' in regard to their choices. Unlike the trend in which urban middle class parents decamp to the suburbs or select private schools when their children reach school age (Kimelberg \& Billingham, 2012), these parents resisted this pathway.

Researchers have begun to examine these types of families and their motivations for remaining in city centers and city public schools (Billingham, 2017; Billingham \& Kimelberg, 2013; Cucchiara, 2013a; Cucchiara \& Horvat, 2014; Posey, 2012; Posey-Maddox et al., 2014; Reay et al., 2011; Stillman, 2012). These parents typically see themselves as liberal urbanites who value diversity and "real world" school experiences and settings for their children. Less research, however, has explored this group's attitudes towards some of the alternatives: private schools and suburban public schools. This paper, therefore, examines these factors, asking: 1) What attitudes and sentiments do city-dwelling, middle class parents with children enrolled in public schools hold towards private schools? 2) What sentiments do these parents have towards suburban public schools? 3) What factors influenced these parents to hold these attitudes and feelings towards private schools and suburban public schools?

To understand these processes, this paper relies on in-depth interviews with parents who have enrolled their children in the City School District of Albany, NY. Using a combination of social identity theory and the rational choice framework, I document that these parents acted both in an objective, calculating, or instrumental approach as it related to school quality, while also providing subjective, personal, or interpretive accounts of their school choices related in part to their identities. Part of the decision-making process involved reflective and 'meaning-making' work pertaining to the type of person each thought of themselves as and how this would be reflected in their community and school choices.

\section{Literature Review}

The existing studies in school choice document that parents take into account numerous factors when determining their children's school enrollment. What may be surprising is that academic quality is often not the only or even main variable in such decisions. For example, parents often move to communities and enroll their children in schools through the assistance of their social networks. Parents turn to family members, friends, and coworkers to obtain recommendations on communities and schools (Lareau, 2014). Because social networks in the U.S. are heavily segregated by race and social class, parents often end up in communities and schools that mirror their social backgrounds (Lareau, 2014; Sattin-Bajaj \& Roda, 2018). Meanwhile, most white parents view majority black and Hispanic schools as undesirable (Billingham \& Hunt, 2016), and segregation by race in America's public schools has increased markedly since the 1980s (Johnson \& Nazaryan, 2019; Logan, Minca, \& Adar, 2012). Relatedly, the convenience of the school's location, behavioral and discipline standards, and the perceived safety of the school are all primary factors in school decisions (Lareau, 2014; Schneider, Teske, \& Marschall, 2000).

To be sure, parents value academic quality, but many, particularly those who are white, conflate academic quality with predominantly white schools. Relatedly, white parents often overlook or simply refuse to send their children to high-performing schools that have majority black or Hispanic student bodies (Billingham, 2017; Billingham \& Hunt, 2016). Moreover, parents utilize their highly homogeneous social networks in their inquiries into teachers, the student body, 
and the overall school environment rather than using more objective, academic metrics and data that states and school districts collect (Holme, 2002). Ultimately, school choice patterns both effect and are affected by longstanding institutional patterns and inequities.

In regard to private schools, studies indicate parents often opt for them when local public schools are deemed unsatisfactory in some way. Billingham and Kimelberg (2013) and Goldring and Rowley (2006) find that parents select private schools in order to have more control over their children's education, including greater access to teachers and school staff. Billingham and Kimelberg (2013), for example, found that Boston parents who enrolled their children in the city's public elementary schools, often left for private schools or the suburbs once their children reached middle school or high school. They felt the city's public middle and high schools were too big, making parental control out of reach. Yet, other studies indicate that "pull" factors pertaining to private schools generally outweigh what "pushes" families away from public schools. These factors include the religious values espoused in private, parochial schools, the lure of smaller class sizes, the belief that children should wear uniforms, and how these schools differ in their approaches to disciplinary and behavioral standards (Lankford \& Wyckoff, 1992).

A growing body of literature, however, has begun to examine the experiences of urban middle class parents who forgo private school options and remain in central-city public schools (Cucchiara, 2013a; Cucchiara, 2013b; Posey-Maddox, 2016; Posey-Maddox et al., 2014; PoseyMaddox et al., 2016). These studies have mostly focused on white middle class parents of children who are at the elementary school level. These parents enroll their children in city public schools for various but inter-related reasons. First, enjoying the unique lifestyle city living provides, they have decided to settle in central cities rather than suburban areas (Billingham \& Kimelberg, 2013; Cucchiara \& Horvat, 2014). Some are also drawn to the diversity in urban public schools, settings that reflect the "real world" (Cucchiara, 2013b). Additional parents are open to "trying out" the public schools in their urban neighborhoods (Stillman, 2012), whereas others have left-leaning political values and support urban public education as a social justice concern (Cucchiara, 2013b; Cucchiara \& Horvat, 2014; Posey, 2012; Reay et al., 2011; Roda, 2018; Stillman, 2012). Other parents are turned off by the perceived, obsessive parenting styles they contend are more prevalent in wealthier, suburban schools (Cucchiara, 2013b; Stillman, 2012).

Although this literature has provided a myriad of new findings, gaps in the scholarship remain. First, most of these reviewed studies have focused - for good reason - on the factors that drew and kept middle class families in city public schools. Less detail and attention have been given to their attitudes and feelings regarding private schools and suburban public schools. Second, most of the aforementioned studies have also focused on white families and their preferences and experiences. In contrast, nearly half of the participants in this study identify as African American or black. The inclusion of African American, middle class families is theoretically salient in that the experience of American public education among the black community has been, and continues to be, drastically different than that of the white population (Lacy, 2007). For a myriad of reasons, African Americans have long been less satisfied with the public education system in comparison to white families (Stulberg, 2008). Therefore, including African American parents in this study adds depth to the literature.

\section{Conceptual Framework}

In this study parents' schooling decisions and their feelings towards private schools and suburban public schools were not unidimensional. Parents sought out academically rigorous schools and programs but also educational settings that both reflected their inclusive values and 
would transmit those values to their children. In this regard, rational choice theory and social identity theory assist in the interpretation of the data. Rational choice theory posits that people are "self-interested utility maximizers" and make decisions and engage in behaviors that best achieve their objectives (Green, 2002). Individuals weigh the pros and cons of each option and avoid actions that would diminish their utility, or the benefits to them. To a considerable extent, parents in this study sought to place their children in the city's best public schools and programs. At the elementary school level, this typically meant selecting certain magnet schools, whereas at the postelementary levels, honors, AP, and IB programs were highly desired.

At the same time, given that parents desired their school choices to be a reflection of their own values while also imparting these to their children, social identity theory assists in this analysis. This theory conceives that people's identity is heavily shaped by their social context, whereby people come to view themselves as members of groups (Ellemers \& Haslam, 2012). People's subjective beliefs about different groups underpin both intra-group and inter-group relations. Most of the participants in this study viewed themselves as urban dwellers committed to diversity and inclusion. They understood themselves as distinct from the parents who sent their children to private schools or those who lived in the suburbs.

Tension existed between desiring the best schools for their children and their egalitarian ideals. Part of this strain might be explained by relatively recent social processes that frame education as a good or product, specifically neoliberal forces that endorse the idea that parents and students are "customers" tasked with "shopping around" for the schools that best meet their needs (Ravitch, 2014). Related to this are market and cultural forces that have encouraged identities to be constructed and reinforced through consumption (Zukin, 2005). This line of research has explored how people come to define themselves by the products they consume, including items as varying as organic food to luxury handbags. These cultural processes have permeated other aspects of social life, and although it may seem unusual to think of schools as "sites of consumption," in an era in which parents are compelled to think of themselves as both consumers and the ones responsible for their children's education, this can inevitably become an aspect of an individual's identity. The growing individualization of educational responsibility parallels growing individualization within the broader society. Similarly, the state's weakening public commitments to education, parallel an overall weakening of collective commitment generally throughout society (Ravitch, 2014).

\section{Case and Methodology}

This research was conducted in Albany, New York, a city of roughly 100,000 residents in a metropolitan region approaching one million. About 10,500 students attend the City School District of Albany. Like other cities in the Northeast, Albany has suffered from both population decline and white flight since the 1950s, although these trends have reversed and slowed, respectively, during the last decade. The public school population does not reflect the overall city population, with African American students constituting by far the largest group in the public schools, whereas the city is still majority white. The public schools in Albany, however, have never reflected the city's broader population. This was mainly due to the sizable Roman Catholic parochial school presence in Albany, which always attracted large segments of children from Irish, Italian, and Polish American families (Rabrenovic, 1996).

Substantial problems face Albany Public Schools. In 2015, the New York State Department of Education (NYSED) placed three schools into receivership, including Albany High School. Under receivership, the state appoints a "receiver," with the power to make substantial changes to 
a school, including firing the school principal and other administrators, extending the school day, and instituting new curricula and programs. Despite the overall district's subpar performance, specific neighborhood elementary schools and elementary magnet schools perform relatively well (NYSED, 2018). The district also operates a highly touted high school International Baccalaureate (IB) program.

The data for this study come from in-depth interviews with forty-four parents. I recruited six participants through my professional networks. Nine participants were recruited at public meetings of the district school board in Albany, and the remaining twenty-nine participants were reached through snow-ball sampling techniques. I have neither children in, nor any professional connections to the Albany public schools. Overall, this was a purposive sample that focused on middle class parents who had remained in the city of Albany and had chosen to enroll their children in the city's public schools. Because this study focuses on middle class parents, the participants had to meet income and education thresholds. Participants had to hold more than a high school diploma and have incomes of over $\$ 48,500$. This figure represents 200 percent of the poverty line for a family of four in 2015 when data collection began (U.S. Department of Health and Human Services, 2015). Table 1 displays the participants' demographic data.

Table 1

Social Characteristics of the Sample

\begin{tabular}{lc}
\hline Characteristic & No. of respondents $(\%)$ \\
\hline Race/Ethnicity & $25(56.8)$ \\
\hline White & $19(43.2)$ \\
Black/African American & $\$ 120,000$ \\
Median Household Income (42 households) & $9(21.4)$ \\
$\$ 50,000$ to $\$ 74,999$ & $16(38.1)$ \\
$\$ 75,000$ to $\$ 124,999$ & $10(23.8)$ \\
$\$ 125,000$ to $\$ 174,999$ & $7(16.6)$ \\
$\$ 175,000$ to $\$ 240,000$ & \\
Education (highest degree earned) & $27(61.4)$ \\
Graduate degree & $9(20.5)$ \\
Bachelor's degree & $8(18.1)$ \\
Associate's degree & \\
Number of Families \& Level of Children & $17(40.5)$ \\
Elementary School Only & $1(2.3)$ \\
Middle School Only & $7(16.7)$ \\
High School Only & $9(21.4)$ \\
Elementary and Middle School & 0 \\
Elementary and High School & $4(9.5)$ \\
Middle and High School & $4(9.5)$ \\
Children at all levels &
\end{tabular}

I focus on middle class families because previous research suggests that, possessing greater resources, they are far more likely than their lower-income counterparts to achieve their school preferences (Lareau, 2014). The qualitative approach of in-depth interviews is also appropriate given this study's aim at attempting to understand the complex ways in which parents choose schools and how this relates to meaning-making (Charmaz, 2014). The interviews were conducted in coffee shops, the participants' homes, and in my campus office. Interviews were semi-structured 
with open-ended and subsequent follow-up and probing questions. Examples of questions were, "what led you to enroll your children in Albany's public schools?" "What have your children's experiences been like in Albany's public schools?" "Did you or your spouse ever consider private schools?" "What led you to remain in the city of Albany?" "Have you or your spouse ever considered moving to the suburbs?" Therefore, this study used both deductive and inductive approaches. The former included pre-planned questions, whereas the latter arose from the interpretation of the participants' unique responses and narratives.

The interviews ranged from 45 to 120 minutes, were audio recorded, and subsequently transcribed verbatim. All of the participants' names and the schools their children attended were altered for confidentiality. The only exception to this was Albany High school, which is the city's sole public high school. After completing five transcriptions, I uploaded the transcripts in Atlas ti qualitative software and began initial coding of the transcripts for key words, repetitive answer patterns, and common descriptors. After coding five transcripts, I subsequently uploaded, coded, and analyzed the remaining transcripts before returning to reanalyze the initial five transcripts for any codes that had emerged in the latter interviews. Atlas ti was also used in this inductive analysis to identify exceptions, sort, and group codes. After initial coding, focused coding was performed to assist in the aggregation of broader themes (Charmaz, 2014). Themes centered on skepticism regarding the superior quality of private schools, feelings of elitism in private schools, lack of services in private schools, heightened peer pressure and competition in suburban public schools, and elitism in suburban schools. Out of these thematic summaries arose the conceptual framework for the paper.

\section{Findings}

\section{Questionable Quality of Private Schools and Suburban Public Schools}

The parents in this study held no, one particular attitude towards private schools and suburban public schools. Parents' feelings towards these schools rested on various factors. Some parents had once enrolled at least one of their children in private schools only to pull them out when circumstances did not meet their expectations. Similarly, a couple families had moved from the city to the suburbs, only to move back after dissatisfaction arose with suburban public schools. Relatedly, moving to the suburbs and enrolling their children in suburban public schools was actually seen by most parents as the less desirable option of the two should their satisfaction with the city public schools erode. Most of the participants in this study viewed themselves as "city people," with only three of the forty-four preferring a suburban residence over city living.

Importantly, the parents in this study had been quite successful at placing their children in the most desirable schools and academic programs the city schools had to offer. At the elementary school level this meant enrolling their children in lotteries to enter the city's best magnet schools, whereas at the middle and high school level, parents sought to place their children in honors and Advanced Placement (AP) and IB programs, respectively. These factors made both private schools and suburban public schools less relevant or needed among most of the parents in this study. Despite Albany High's overall poor academic rankings, the quality of the IB program (with about 100 students total), made this school desirable for families with high performing children. Most of

the families with children at the high school level emphasized the IB factor at Albany High. This included Edith, a mother of two children, one of whom is currently attending Albany High.

I: Do you think the quality of Albany High is just as good \{as private school $\}$ ? 
E: Phenomenal...If you have a certain type of student, a high-performing student, the high school cannot be beat. My freshman daughter is taking AP biology; she's taking IB Chinese, Spanish 4, Honors English, Algebra 2. You can't do that in the suburbs.

Diane, a parent with two children at the high school level, noted that many of the parents of her children's friends moved to the suburbs when they reached middle school. Because of this she also considered the suburbs, but she and her husband decided against it. She notes:

I was worried that they were missing something, that they weren't going to get from the city schools, but I never found that. In fact, by the time they got to high school, I was really amazed by what Albany High School has to offer, if you were willing to work hard, and having the IB program. It's one of the only schools north of \{New York City\} that taught IB Chinese and a lot of AP, a lot of challenging stuff.

The majority of parents with children at the elementary level were able to enroll their children in the city's best magnet schools. Shelley, who has one child in the public schools, enrolled her daughter the district's language immersion school housed within Mapleridge Elementary. Students learn and interact entirely in Spanish two days a week, whereas instruction is in English the remaining days. Shelly explains:

They're truly efficient. I'm completely satisfied... When it comes to Spanish they're extremely thorough. They give ample homework which challenges them, and it's brought about a really focused and well-developed child, which \{my daughter\} is. She's already reading in both Spanish and English at the age of six. I think that's incredible.

Because most parents were relatively happy with the academics in specific public schools, they were not confident private schools or suburban schools could offer markedly better education. The doubts held by parents were also compounded by the large sticker prices of private schools. Reese, a mother who has children in elementary and middle school, explains, "First of all, I don't think the private schools in this area are that good. I mean, they're fine, but are they worth $\$ 17,000$ a year? And they're very small, and I don't think the academics are that much better to justify." Sara, who has one daughter in elementary school, explains, "my parents struggled to put all of us kids through \{Catholic schools\}, and I thought the education was just average." Similarly, Jolene, who has two children in middle and high school, explains:

You know we were looking at Elisa Smith \{a private girls academy\}, and they are so regimented in their curriculum. Our principal at our other school wanted us to consider it because they thought she could get a scholarship, so we went...And we were not impressed with the rigor of the academics there.

Ruth, a mother of four children, considered the same school for her highschoolers and noted, "there's a thought of Elisa Smith for the girls, because I think it's a real, private prep school, a global school, but I still don't think it beats Albany High." 
Some parents had enrolled at least one of their children in private schools at some point only to switch to the city's public schools. Laura, a mother of four who had some of her children off and on in private schools, explains, "I found this over and over again; I found that my kids, they would have amazing teachers and mediocre teachers, and occasionally they would have bad teachers. Even in private schools there are bad and good teachers, and in that situation they don't pay enough, and the good teachers leave after a few years."

Tara initially had some of her children in Catholic schools but has since switched to a magnet public school. She explains, "I'm so glad we switched. The education is so far beyond what they had at Catholic school, and you're paying all that money. And the extracurriculars, like band. My older kids did not have band until their last year \{at the Catholic schools\}." Asked why she thought the public schools in the city were more desirable, she explained:

\section{I think the accountability. The teachers make more \{money at the public schools\}. At Catholic school, in my experience, it's more about the discipline. The whole Catholic thing, the religious instruction. You're not spending time on that in the public schools.}

Recent scholarship may support some of the parents' assumptions regarding private school education. The U.S. Department of Education conducted a series of analyses of American students in public and private schools. Statistical controls adjusted for social characteristics of the students including gender, race/ethnicity, disability status, and identification as an English language learner. The study also adjusted for school size and location, the composition of the student body, and the composition of the teaching staff. With these controls there was no statistically significant difference between the scores of fourth graders for reading, and public school students outscored their private school peers in math by 7.8 points. By eighth-grade, however, private school students slightly outscored public school students in reading, but no differences appeared in math scores (U.S. Department of Education, 2006).

The educational experiences of the parents' children in this study reflect research which suggests that the income level of a child's parents is a better predictor of graduating from college than test scores (Breen \& Jonsson, 2005). Furthermore, family structure, economic insecurity, and parental engagement are better predictors of educational achievement than per-pupil school funding or class size (Breen \& Jonsson, 2005). Given that the median income of this study's families was $\$ 120,000$ and the majority held graduate degrees, the parents' own financial and human capital facilitated their children's academics. Most parents, however, still desired to place their children in the most academically rigorous programs the city school district offered.

Parents' doubts about the superior quality of private schools were also shared in regard to suburban public schools. This came despite state test scores being substantially higher in the area's suburban public schools (NYSED, 2018). Kelsey, a parent with two children who had lived in Albany, then moved to the suburbs before returning to Albany, said the quality of her son's suburban public school was unimpressive. I always had concerns about middle school and what I was going to do with him. And then when I went to North Country, I didn't feel suburban education was any better. Actually, I felt that it was worse. The standards were much lower I felt, and maybe because they didn't have the same kind of pressure to achieve, because, you know, they are always failing schools in the city. So, the city schools have this pressure to perform.

Similarly, Claire, a mother with three children, had lived in two different suburbs before returning to Albany. She explains: 
No, the education in the town wasn't any better. The building is old. It's filled with asbestos because I went in and I was coughing and sneezing. We make this hype about suburban schools. We've been in both, Pine Bush High and Albany High. And I can tell you that at Pine Bush High there were more problems than at Albany High. The same thing at Rockwell Central \{another suburban school\}.

Sandy and Duncan (2010) find a large academic achievement gap between urban and suburban students, but seventy-five percent of the variation was based on the family background and socioeconomic status of the student. Class sizes, the overall size of the school, and whether the school was public or private were not important variables in the disparity between urban and suburban students. It appears the parents in this study have experienced what the broader data suggest. They appear to understand that suburban versus urban, public versus private, are only two variables, and that other factors need to be taken into account when selecting schools.

\section{Private Schools and Suburban Public Schools Have the Same Problems}

Research suggests that concerns over behavioral problems and negative peer pressure are major factors that influence parents to exit city public schools (Goldring \& Rowley, 2006). Parents in this study, however, felt that the same behavioral problems and peer pressures their children faced in city public schools would still be present in private and suburban schools. This influenced parents to remain in the city's public schools.

Ruth's impressions of private schools in the area have been influenced by her friends' experiences at private schools. She explains, "I have a friend at Wild Oaks Academy, and his kid got choked by another student in the class. You know choked, physically choked, where they almost had to call the police choked. She's paying $\$ 12,000$ a year for her kid to get choked!" Carla also had impressions of private schools based on relatives or friends who had children in private schools. She notes, "my niece was \{initially\} in Albany High. She ended up going to a private allgirls school, and she still found the bad crowd. It was a waste of money. It really depends on whether the child wants to get an education or if they want to just goof off."

Other parents had initially placed their children in private schools only to exit because of dissatisfaction with the behavioral climate. Elaine, a mother of two children, explains:

I would say the Hebrew Academy had just a really horrible influence. Bad seeds are everywhere, right? For example, you know, do I think drugs are limited to Albany High? No! Do I think Internet bullying is limited to Albany High? No! Am I exposing my kids to more risk by sending them here? Absolutely not. At the Hebrew Academy there was bullying, and it was kindergarten! I'm horrified that it can even start there.

Ashley, with three children in elementary and middle school, has similar feelings. She believes, however, that racial prejudice and the local media affect the wider perception of the public schools in Albany.

I say that the media focuses on the negative of the city environment and city schools. They prey on people's preconceived notions, but there's plenty of problems in the suburban schools, and actually suburban schools tend to cover up or not display their issues so much. I think they white wash at Pine Bush High. There are things that go down; they cover it up. There's a heroin problem; 
there's definitely other problems there. ... The attitudes about Albany High, I don't say it, but I think some people are just prejudiced [laughing]. I just don't tell them that. Some people are just racist.

Research suggests that certain types of 'delinquent behaviors' are less common in religious private schools than in public schools, but not all behavioral issues. Figlio and Ludwig (2000) found that attending a religious private school reduced the likelihood that students engaged in sexual activity and hard drug use, but it had no effect on marijuana use, drinking, smoking, and gang involvement. Research suggests even less variation between urban and suburban public schools (Greene \& Forster, 2004). Compared to their urban public school peers, sexual activity, alcohol, and cigarette use tended to be higher among seniors in suburban public high schools. The researchers also found no difference in illegal drug use and rates of fighting and stealing between the two groups (Greene \& Forster, 2004).

\section{Distinct Resources and Assets of City Public Schools}

Some parents in this study felt that the Albany public schools could provide better services for their children than other schools. This notion came in part because they believed their children faced less competition from other families for attention and resources. Edith, a mother of two daughters, explained that because the city schools are made up of many families who for various reasons are not as involved as those in the wealthier suburban districts, she has more of a voice in the schools. This was of particular importance to her in that one of her daughters has special needs. She explains:

Do you see where this can be a benefit, being in an urban school district? They don't have a lot of parents lining up saying, 'I want this for my child.' They don't have enough of it. But because there aren't enough \{involved\} parents, they will listen to me, especially when I speak, they know what I'm saying. I think that I know families that are in the suburbs and they have just the same problems that I do, but they don't get listened to because they're a dime a dozen in the suburbs.

The issue of the city schools providing more services to children with special needs was also articulated by Barbara who notes:

I have friends who have children, one in Bethlehem, one in Colonie. In Bethlehem they're having a hard time with special ed services. Again, if you're not college track and you have a special need, some of the schools are less...they're supposed to be adapting; they're supposed to be doing the IED's and 504's. It's all really good, but if it's not happening, it's not helpful to the child.

Both of these parents placed value on the time and attention specific schools gave to their children. These attitudes reflect Billingham and Kimelberg's research (2013) suggesting that parents strongly value parental input and exit urban public middle and high schools that are too large for meaningful parental involvement. Yet, when it came to students with special needs, these parents in Albany felt the city's schools actually allowed for more parental communication and input than the suburban public schools. 
All public schools are required by federal law to provide special education services. Private schools are not required to provide these services, but many acquire resources through neighboring public school districts. These regulations date to the 1975 Education for All Handicapped Children Act, which is now referred to as the Individuals with Disabilities Education Act (IDEA). IDEA also requires that districts provide services and assistance to students with special needs who are enrolled in private schools. In 1982, further progress was achieved through the courts with Board of Education of Hendrick Hudson Central School District v. Rowley. The court decision required that districts not only provide access to services but programs that met the needs of actual students. Beyond federal regulations, states have discretion to offer special education services that are more expansive than federal law. States, however, have the authority to define the guidelines for who qualifies for each disability type. Therefore, these eligibility guidelines and the specific manner in which disability services are provided vary between states and even by districts within each state (Esteves \& Rao, 2008).

Little research exists on the disparities in special education services between urban and suburban school districts. Recent scholarship, however, notes that rural public school districts, due to limited financial resources, struggle to provide the same types of services for special needs students as urban districts (Murphy \& Ruble, 2017; Pennington, Horn, \& Berrong, 2017). Studies of suburban districts, however, have found somewhat contradictory results. Ahram, Fergus, and Noguera (2011) find that students of color in suburban districts are over-represented in special education classes but also do not receive adequate services. The authors attribute this partially to bias-related misdiagnoses of students of color that subsequently place them in settings that fail to provide the instruction they actually need. To be sure, the over-representation of students of color in special education classes exists in urban public schools as well (Skiba et al., 2008).

Analogous to the notion that their children would be provided with better, additional services should their child ever experience the need, many parents believed their child would, in general, receive more attention in the city public schools in comparison to suburban schools. Some explained that because the Albany public schools had fewer high-achieving students than the suburban districts, their children would find it easier to stand out or attain distinction in either academics or athletics. On the other hand, parents also felt that intense competition could also go too far. A good balance was the ultimate goal. Jolene explains:

You find that the competition is so fierce in the suburbs to get into honors classes; you could be a tenth of a point off your GPA in eighth grade, forget it, you're not going into honors classes...It's competitive at Albany too, but the pool is not so big, so that \{my daughter\} has the opportunity to shine. They're hungry for smart kids at Albany High.

Greg, a father of three children, noted that beyond the excessive competition in the suburban public schools, he felt that his oldest child who is now in college, got an advantage in college admissions from attending an urban high school.

I'm not convinced that the academic competition and pressure the suburban kids have for good grades and things like that is good. Our kids don't feel that in Albany. And so, whereas their averages and scores might be higher in the suburban schools, I don't think that type of pressure on the kids is a good thing... But it's a tradeoff, and I think that when my oldest applied to colleges, I think colleges recognized that fact. So, when the kids are applying from an urban school with an 85 average, they might be put in the pool with kids applying from suburban schools with 95 averages. The colleges adjust for that. 
Sara similarly notes the outsized competition in the suburbs and the advantages of her children attending urban schools.

Colleges, you know, want diversity, and that includes having students who come from urban high schools. My kids are going to have that. Plus, the stress of the suburban schools are sometimes much greater. You know, I have a friend of mine, grew up in the Albany schools, her daughter is thirteen or fourteen...Lacrosse is the big thing now, you know, it's huge. So, the suburban coach said, 'Go to this camp up at Siena' \{a local private college\}...They don't make that much money. So, she sends her to this very expensive camp....So, she tries out; she doesn't make the team; kid is devastated.

To the author's knowledge, no research has been conducted comparing the "positive," competitive-peer pressure between urban and suburban public schools. Existing research has focused more on how urban middle class families dislike the obsessive parenting styles they assume are more common among families in affluent suburban public schools (Posey-Maddox, et al., 2014). Yet, positive peer-pressure and peer competition have major impacts on individual

student and school-level performance, above and beyond school administration policies (Rothstein, 2006). Comprehensive research, however, suggests that schools with the best academic performance tend to emphasize cooperative, group-based, problem-solving projects rather than curricula designed around individual goal structures and competition (Roseth, Johnson, \& Johnson, 2008).

\section{Parental Identity and the Social Environments of Private Schools and Suburban Schools}

A final and central theme concerns parents' conceptions of themselves and the values they want to impart to their children. Parents' support of city public schools was, in part, based on their own political values regarding public education. They felt that enrolling their children in either private schools or suburban public schools would undermine their beliefs surrounding diversity, inclusion, and egalitarianism. Private and suburban public schools, filled disproportionately with wealthier children, were felt to be too elitist and insular. These dynamics have been found in previous studies among white middle class urban parents (Cucchiara \& Horvat, 2014; Posey, 2012). Among this study's participants, however, African American parents were just as likely to express these sentiments as white parents. In this final section, quotes will be introduced with the racial background of the parent.

Shauna, an African American mother of two children, explains, "Did we ever consider private school? No. Because, I just...why didn't we do it? I guess the elitism of it. I didn't want that." Karisa, a white mother with two children, explains in regard to private schools:

In some ways they might be better, technically, possibly, true, but at the same time, who attends private school, right?... Usually the privileged. So, I really wanted my kids to live a real life and be around children of all different types. I actually went when I was young to a very suburban white school, and there were things even then as a young kid, I knew did not seem right to me, even then.

Brenda, a white parent with two children, also explains:

And I will say, somebody I know who, her kid, a kid I know who is my daughter's age, who goes to a private school, when he hangs out with his 
public school friends and spends time with their African American friends, he doesn't know how to relate to kids who don't have i-Pods, who don't drive fancy cars, whose parents don't even have a car. I don't want that for my kid.

Ashley, a white parent with three children, has similar feelings, but with children and families from suburban public schools. Her ex-husband has joint custody with their daughter who, although attending a suburban school, participates in extracurricular activities in the city.

Stuff, social status, and...clothing, and i-Phones, and shoes, and fancy Uggs. Then also the way her friends talk about people of color and poor people. I have to spend a lot of time working with her - she does Albany Youth Soccer - and she does more stuff in the city than she would ever do otherwise, and that helps her. But we have to constantly work with her against the pressure of judging the city. I mean, she gets told that the whole city is a ghetto and she wasn't allowed to have friends come visit us.

Parents spoke of a desire to instill empathy or respect for people from less fortunate backgrounds. They believed that to instill empathy, one had to live that experience. Simply speaking to their children about the importance of respect for differences was not enough. Parents who wished to instill empathy said they had to connect those words to real life exposure. Ruth, a white parent of four who lives in a downtown neighborhood, explains:

My husband and I don't want our children surrounded in some of the things that the private school parents have said or the kids have said about poor people... We have our children out in the neighborhood... \{My daughter's\} quartet played in front of the wine shop on Lark and raised $\$ 80$ for the pet shelter. I want them to have that experience. They ride their bikes on Lancaster. They see homeless people and learn not to judge.

Ramona, an African American parent of two children, explains:

I like that \{my child's public school\} is urban because the fact of the matter is, hunger exists. It doesn't not exist. Pain and economic struggle exist. Black people exist. Hispanics exist. So, to raise my children in a world that's not representative of that, um, isn't fair. I believe in the public school system. I believe that it's what the populations do. We have the right to be educated.

Cindy, a white mother of a son in elementary school, also explains:

When you send your kid to the Albany public schools, you really confront head on issues of racism and classism that you can avoid if you live in the suburbs. Those issues still exist, but if you're sending your kids to a 95 percent white school where no one gets a free lunch, you can avoid the issues...Sending your kid to the Albany public schools...you can't escape these issues. It's a huge drawback when people aren't getting exposed. 
That's something that has been a big added benefit to the city public schools -that \{my son\} really is a lot more socially aware.

Finally, Brooke, an African American parent with two children, echoes these sentiments. She and her husband moved into Albany from the suburbs because they felt they needed to live out what they were expressing to friends and family members about inclusion. She explains:

So, the reason why I didn't consider putting my kids in private school? It was partially budget, but a lot of it had to do with the fact that I care about public education, and I care about all of the kids in all of the schools getting a great education. I want to be a parent that helps make change happen in the public schools. Both my husband and I felt strongly about that...There are stigmas attached to city schools that don't always belong there. We need to be able to break some of that. For a short time I used to be one of those parents who just wanted to protect their kids, and I was like, 'I'll take my little brown kids to a white school to get them a great education-that's what I'm going to do.'But then I had to check myself a little bit and say, is that really what I'm trying to teach my kid? Is that what I honestly believe? And I realized that I don't feel that way. That's not who we are.

For many of the parents in this study the belief in urban public education became part of their identities and how they came to understand themselves. Importantly, this identity construction process was as prevalent with the African American parents as it was with white parents. This is relevant given that, in comparison to whites, African Americans have long been less satisfied with American public schools (Stulberg, 2008). Furthermore, on their list of school priorities, studies suggest that African American parents place academic quality ahead of racial integration and racial diversity (Lareau, 2014; Stulberg, 2008).

In other ways, the participants' outlooks on private schools complement the existing literature in that private school "choosers" tend to be more socially and politically conservative than "non-choosers." They are also more likely to hold "traditional" values surrounding discipline, gender roles, and religion (Beavis, 2004; Goldring \& Rowley, 2006). This study's parents, in contrast, held overwhelmingly progressive political outlooks and articulated how they wanted these values to be transmitted to their children.

The contrasts that the parents in this study construct between them and private- and suburban public school parents reflect the identity-making processes groups undertake in which their group concept is in part defined by constructing and upholding boundaries between themselves and other groups (Ellemers \& Haslam, 2012). The parents in this study are, in part, defining how and what they desire their children to be like by articulating what they perceive to be the negative traits of other parents and children, families whom they define by their divergent residential and educational choices.

\section{Conclusion}

This paper explored the attitudes and feelings middle class, city-dwelling parents held towards private schools and suburban public schools. Parents' generally negative outlooks on these types of schools were multi-factored. First, these parents were largely skeptical of the superior quality of private and suburban public schools. Part of this, however, derived from their ability to 
strategically place their children in the city district's best magnet programs as well as IB and AP programs at the elementary and post-elementary school levels, respectively. Their children were among a minority of students with access to the top programs the district offered. Parents also noted their enhanced access to special education services in the city in comparison to other schooling options. Finally, many parents stated that because of the urban setting amidst many underperforming students, their children's academic abilities would stand out. Their children would essentially be "a big fish in a small pond." The findings suggesting that parents believed their children would receive extra services, attention, notability, or even preferred college entrance because of their city school backgrounds go beyond a desire for high quality school programs noted in previous studies (Cucchiara, 2013b; Stillman, 2012).

These largely instrumental reasons for selecting urban public schools were joined with more philosophical factors tied to parents' identities. Parents believed that private schools and suburban public schools were too elitist and insular. They thought of themselves as having an egalitarian ethos that valued inclusion and diversity. They felt that enrolling their children in urban public schools not only reflected their values but would impart the same egalitarian values to their children. Essentially, urban public school "consumption" would satisfy these ends.

The findings on parental identities reflect research by Cucchiara and Horvat (2014), who focused on white middle class urban parents. Yet this study found that middle class African American parents were just as likely as white parents to have a philosophical attraction towards the diversity and inclusivity found in urban public schools. The latter factor is important given both the historic and contemporary obstacles African American parents encounter in the public education system. Studies suggest that black children are still at greater risk than their white counterparts to be unfairly tracked into remedial programs (Ersoy \& Uysal, 2018; Stulberg, 2008). They also face negative stereotyping by teachers and school staff that limits their educational advancement (Logan et al., 2012). This is one reason why many middle class African American parents choose private schools for their children over public schools (Lacy, 2007; Pattillo, 2015). Unlike these previous studies, however, the African American parents were quite satisfied with the schools and programs offered by Albany's public schools. Their children were successfully placed in the district's top programs, notably the highly regarded IB program at Albany High.

Although I can only make limited generalizations based on this case and sample, the findings suggest first that for some middle and upper middle class urban residents, public schools may not be desirable unless districts offer families a substantial array of honors, AP, and IB courses or distinctive "gifted and talented" programs. Second, because these programs draw more affluent parents, will the investments in these areas reduce resources for the remaining students who are not enrolled in these specialized programs? Furthermore, because many parents in this study deemed magnet schools to be more desirable than their neighborhood schools, it is possible for savvier parents with greater access to information to monopolize seats in magnet programs. Parents with smaller and less sophisticated social networks may be cut out of seats at these schools. In light of this, districts might have to make particularly great efforts to inform residents through numerous and diverse venues of the various public school options. Finally, and central to this paper's findings, is that there are middle class urban parents that admittedly dislike both the idea of private school education and suburban living. This study cannot measure what percentage of the American public feels this way, but the findings underscore the political salience for investing in American public education. A constituency of middle class urban parents with preferences for public education does exist, and elected officials would be wise to be conscious of this, especially when ideas such as privatization and charter schools are debated. 
In addition to the limitations already spelled out, other limitations in this study include the cross-sectional nature of the data. Longitudinal data tracking these families' experiences over time would produce more robust findings and add veracity to parents' claims regarding their motivations behind school choice. As a comparison to the families in this study, additional data could be collected from those who exited the city's public schools for private or suburban public schools. This would assist in drawing out the factors that led to varying outcomes. The same process could also be done with parents who select charter schools. The in-depth qualitative data in this study could also be added to survey-based data from a larger population of urban middle class residents.

Overall, this study suggests that while urban middle class parents who select public schools do value diversity and inclusion in schools and undertake identity work surrounding their choices, instrumental motivations surrounding school quality, peer competition, access to enhanced services, and even a 'leg-up' on college admissions were important in their school decisions. Furthermore, parents' skepticism that private and suburban public schools offered both a better education and a safer environment for students was just as central in their narratives as their sentiments that these schools were insular and elitist. These findings reflect the continued cultural force of neoliberalism (Ravitch, 2014) that privileges the idea that individual parents are ultimately responsible for the educational choices and outcomes of their children. Therefore, they will "do what it takes" to ensure their children's academic success.

\section{References}

Achieving equity in special education: History, status, and current challenges. Exceptional Children, 74(3), 264-288. doi:10.1177/001440290807400301

Ahram, R., Fergus, E., \& Noguera, P. (2011). Addressing racial/ethnic disproportionality in special education: Case studies of suburban school districts. Teachers College Record, 113(10), 2233-2266.

Beavis, A. (2004). Why parents choose public or private schools. Research Development, 12(3).

Berkeley, CA: University of California Press.

Billingham, C. (2017). Waiting for bobos: Displacement and impeded gentrification in a midwestern city. City \& Community, 16, 145-168.

Billingham, C., \& Hunt, M. (2016). New evidence on the preferences of white parents in the

Billingham, C., \& Kimelberg, S. (2013). Middle class parents, urban schooling, and the shift from consumption to production of urban space. Sociological Forum, 28(1), 85-108. doi:10.1111/socf.12004

Breen, R., \& Jonsson, J. (2005). Inequality of opportunity in comparative perspective: Recent

Charmaz, K. (2014). Constructing grounded theory. Los Angeles, CA: Sage Publications.

Chiodo, A., Hernández-Murillo, R., \& Owyang, M. (2010). Nonlinear effects of school quality on house prices. Federal Reserve Bank of St. Louis Review, 92(3), 185-204.

Cucchiara, M. (2013a). Are we doing damage? Choosing an urban public school in an era of parental anxiety. Anthropology \& Education Quarterly, 44(1), 75-93. doi:10.1111/aeq.12004

Cucchiara, M. (2013b). Marketing schools, marketing cities: Who wins and who loses when schools become urban amenities. Chicago, IL: University of Chicago Press.

Cucchiara, M., \& Horvat, E. (2014). Choosing selves: The salience of parental identity in the school choice process. Journal of Education Policy, 29(4), 486-509. doi:10.1080/02680939.2013.849760 
Ellemers, N., \& Haslam, S. (2012). Social identity theory. In P. A. M. Van Lange, A. W. Kruglanski, \& E. T. Higgins (Eds.), Handbook of theories of social psychology (pp. 379398). Thousand Oaks, CA: Sage Publications.

Ersoy, E., \& Uysal, R. (2018). Opinions of School Psychological Counselors on Giftedness and Gifted Students' Education. American Journal of Qualitative Research, 2(2), 120-142.

Esteves, K., \& Rao, S. (2008, November/December). The evolution of special education: Retracing legal milestones in American history. Principal. Retrieved from https://www.naesp.org/sites/default/files/resources/1/Principal/2008/N-Oweb2.pdf

Figlio, D., \& Ludwig, J. (2000, November). Sex, drugs, and Catholic schools: Private schooling and non-market adolescent behaviors. National Bureau of Economic Research.

Goldring, E., \& Rowley, K. (2006). Parent preferences and parent choices: The public-private decision about school choice. American Educational Research Association.

Green, S. (2002). Rational choice theory: An overview. Baylor University faculty development seminar on rational choice theory. Baylor University Department of Economics.

Greene, J., \& Forster, G. (2004). Sex, drugs, and delinquency in urban and suburban public schools. Center for Civic Innovation at the Manhattan Institute. Retrieved from

Holme, J. J. (2002). Buying homes, buying schools: School choice and the social construction of school quality. Harvard Educational Review, 72(2), 177-205. doi:10.17763/haer.72.2.u6272x676823788r

https://media4.manhattan-institute.org/pdf/ewp_04.pdf

Johnson, R., \& Nazaryan, A. (2019). Children of the dream: Why school integration works. New York: Basic Books.

Kimelberg, S. (2014). Beyond test scores: Middle-class mothers, cultural capital, and the evaluation of urban public schools. Sociological Perspectives, 57(2), 208-228. doi:10.1177/0731121414523398

Kimelberg, S., \& Billingham, C. (2012). Attitudes toward diversity and the school choice process: Middle class parents in a segregated urban school district. Urban Education, 48. doi:10.1177/0042085912449629

Lacy, K. (2007). Blue-chip black: Race, class, and status in the new black middle class.

Lankford, R. H., \& Wyckoff, J. H. (1992). Primary and secondary school choice among public and religious alternatives. Economics of Education Review, 11, 317-337. doi:10.1016/02727757(92)90040-A

Lareau, A. (2014). Schools, housing, and the reproduction of inequality. In A. Lareau \& K. Goyette (Eds.), Choosing homes, choosing schools (pp. 169-206). New York, NY: Russell Sage Foundation.

Logan, J., Minca, E., \& Adar, S. (2012). The geography of inequality: Why separate means unequal in American public schools. Sociology of Education, 85(3), 287-301. doi:10.1177/0038040711431588

Murphy, M., \& Ruble, L. (2017). A comparative study of rurality and urbanicity on access to and New York State Department of Education. (2018). Retrieved from https://data.nysed.gov/

Pattillo, M. (2015). Everyday politics of school choice in the black community. DuBois Review, 12(1), 41-71.

peer relationships: The effects of cooperative, competitive, and individualistic goal structures. Psychological Bulletin, 134(2), 223-246. doi:10.1037/0033-2909.134.2.223

Pennington, R., Horn, C., \& Berrong, A. (2017). An evaluation of the differences between big city and small town special education services for students with low incidence disabilities in 
Kentucky. Rural Special Education Quarterly, 28(4), 3-9. doi:10.1017/S1742058X15000016

Posey-Maddox, L. (2016). Beyond the consumer: Parents, privatization, and fundraising in U.S. urban public schooling. Journal of Education Policy, 31, 178-197

Posey-Maddox, L., Kimelberg, S., \& Cucchiara, M. (2014). Middle class parents and urban public schools: Current research and future directions. Sociology Compass, 8, 446-456. doi:10.1111/soc4.12148

Posey-Maddox, L., Kimelberg, S., \& Cucchiara, M. (2016). Seeking a critical mass: Middle class parents' collective engagement in city public schooling. British Journal of Sociology of Education, 37(7), 905-927.

Posey, L. (2012). Middle- and upper middle-class parent action for urban public schools: Promise or paradox? Teachers College Record, 114, 1-43.

Rabrenovic, G. (1996). Community builders: A tale of neighborhood mobilization in two cities. Philadelphia, PA: Temple University Press.

Ravitch, D. (2014). Reign of error: The hoax of the privatization movement and the danger to America's public schools. New York, NY: First Vintage Books.

Reay, D., Crozier, G., \& James, D. (2011). White middle class identities and urban schooling. Palgrave.

research on educational attainment and social mobility. Annual Review of Sociology, 31, 223-243. doi:10.1146/annurev.soc.31.041304.122232

Roda, A. (2018). School choice and the politics of parenthood: Exploring parent mobilization as a catalyst for the common good. Peabody Journal of Education, 93(4), 430-449.

Roseth, C., Johnson, D., \& Johnson, R. (2008). Promoting early adolescents' achievement and

Rothstein, J. (2006). Good principles or good peers? Parental valuation of school characteristics, Tiebout equilibrium, and the incentive effects of competition among jurisdictions. American Economic Review, 96(4), 1333-1350.

Sandy, J., \& Duncan, K. (2010). Examining the achievement test score gap between urban and $\begin{array}{llll}\text { suburban students. Education } & \text { 297-315. }\end{array}$ doi:10.1080/09645290903465713

satisfaction with services for children with autism spectrum disorders. Rural Special Education Quarterly, 31(3), 3-11. doi:10.1177/875687051203100302

Sattin-Bajaj, C., \& Roda, A. (2018, October). Opportunity hoarding in school choice contexts: The role of policy design in promoting middle-class parents' exclusionary behaviors. Education Policy. doi:10.1177/0895904818802106

Schneider, M., Teske, P., \& Marschall, M. (2000). Choosing schools: Consumer choice and the quality of American schools. Princeton, NJ: Princeton University Press.

Sikkink, D., \& Emerson, N. (2008). School choice and racial segregation in US schools: The role of parents' education. Ethnic and Racial Studies, 31(2), 267-293. doi:10.1080/01419870701337650

Skiba, R., Simmons, A., Ritter, S., Gibb, A., Rausch, M., Cuadrado, J., \& Chung, C. (2008).

Stillman, J. (2012). Gentrification and schools: The process of integration when whites reverse flight. New York, NY: Palgrave.

Stulberg, L. (2008). Race, schools, and hope: African Americans and school choice after Brown. New York, NY: Teachers College Press.

U.S. Department of Education. (2006). Comparing private schools with public schools using hierarchical linear modeling. Retrieved from https://nces.ed.gov/nationsreportcard/ pdf/studies/2006461.pdf 
U.S. Department of Health and Human Services. (2015). 2015 Poverty Guidelines. Retrieved from https://aspe.hhs.gov/2015-poverty-guidelines

United States. Sociology of Education, 89(2), 99-117. doi:10.1177/0038040716635718

Zukin, S. (2005). Point of Purchase. New York, NY: Routledge.

Manuscript received July 17, 2019

Final revision received September 06, 2019

Accepted October 25, 2019 